\title{
Sakprosaens kraft
}

Å forbigå Covid-19-pandemien i stillhet i en lederartikkel medio april 2020 vil i seg selv være en ytring. En slik tilbakelent ytring ønsker vi ikke å bidra med, og vi kjenner oss sikre på at tidsskriftet i framtiden vil bringe analyser av tekster som er preget av denne omkalfatrende serien av begivenheter. Tidsskriftet Sakprosa dreier seg om tekster, ofte tilsynelatende trivielle ytringer, som gjør noe. «How to do things with words», het John Austins berømte språkfilosofiske bok, utgitt for 60 år siden. Ofte tenker vi fremdeles på et ord som «smittevern»som rent deskriptivt. Men slike ord oppstår alltid i en kontekst, og der det er kontekst, er det handling.

Sakprosaen er full av handlende, «virksomme ord», enten de ytres av en svensk smitteverngeneral, en norsk helseminister eller i de tusen hverdagssjangrene som omgir oss til daglig og som akkurat nå preges av pandemien. Men i den nye virkeligheten, som hjemmelærere for barna våre, permitterte, arbeidsløse, frilansere uten oppdrag eller universitetslærere uten adgang til campus, glemmer vi lett at den enkeltes handling overfor viruset inngår i et stort, daglig kretsløp av sakprosatekster: Fra oppslaget utenfor butikken til unntakslovene. Korona-periodens tekster kommer til å bli flittig studert i mange årtier framover, utfra store spørsmål som: Hvorfor skiltes Sverige så plutselig fra resten av Norden? Hvilken rolle spilte helsefaglige og politiske ytringer da hver nasjon skulle samordnes normativt og praktisk? Og utfra hverdagsnære, men like viktige forskningsspørsmål: Hvordan bidro de mer eller mindre sosiale mediers sakprosa til å fremme eller hemme solidaritet i lokalsamfunnene?

I medisinsk, epidemiologisk forskning kan en én måned gammel klinisk studie av Covid-19 være eldgammel for den som vil følge forskningsfronten. Men dette er unntaket. Akademisk publisering går vanligvis langsomt for seg, og skal så gjøre. Arbeidet med hver av de tre artiklene vi presenterer i dette nummeret startet for flere år siden, og selv om de er énforfatter-artikler, er de resultat av kollegialt samarbeid og gransking.

Sanna Skärlund undersøker kritisk bruken av særlig et begrep som utvilsomt har vært virksomt, helt siden Brundtland-kommisjonen lanserte det for alvor i 1986: bærekraft/hållbarhet/sustainability. Materialet er svenske statsselskapers årlige «verksamhetsberättelser». At «bærekraft» er mye av et «buzz-word», vet vi alle. 
Men det betyr selvsagt ikke at forfatterne av tekstene ikke utfører handlinger med begrepet.

Begge de to øvrige artiklene tar utgangspunkt i det norske Pax forlags oversettelser av fransk intellektuell litteratur. Anje Müller Gjesdal undersøker i en eksplorativ og kvalitativ studie hvordan kjønnsrelaterte uttrykk oversettes til norsk, og spør om oversettelsene har gitt en mer «fransk» kjønnsforståelse innen de humanistiske fagene her nord. Geir Uvsløkk gransker hvordan bøkenes paratekster - særlig etterordene - og anmeldelsene til sammen skapte et formidlingsfellesskap som kan ha bidratt til at samtidig fransk humanistisk og samfunnsvitenskapelig tenkning har fått fotfeste i Norge.

Heller ikke disse artiklene er tilbakelente og indifferente ytringer, men forskningsbidrag som forsøker å begripe sakprosaens kraft. 